Acta Biologica Plantarum Agriensis 5(1): 34 (2017) ISSN 2061-6716 (Print), 2063-6725 (Online) http://abpa.ektf.hu/
DOI:10.21406/abpa.2017.5.1.34

$4^{\text {th }}$ CC 2017 Abstract Lecture

\title{
ECOPHYSIOLOGY OF BRYOPHYTES IN THE CHANGING ENVIRONMENT
}

\author{
Moha-ökofiziológia a változó környezetben
}

\section{Marianna MARSCHALL}

Eszterházy Károly University, Institute of Biology, Department of Botany and Plant Physiology, 3300 Eger, Leányka u. 6.; e-mail: marschall.marianna@uni-eszterhazy.hu

Studies of the impact of climate change on plants are generally based on vascular plants. Bryophytes basically differ from tracheophytes in having a smaller size and a poikilohydric strategy for water and nutrients. Their survival and growth are highly dependent on their external environment. Bryophytes are able to lose most of their cell water without dying, and resume normal metabolism after rehydration, gaining positive carbon balance over wet-dry cycles. This is sort of adaptation is called desiccation tolerance. Desiccation tolerance is a common but not unique phenomenon among bryophytes: cells of bryophytes in exposed sunny sites can switch from full turgor to air dryness quickly, while the species of moist habitats dry more slowly, and can suffer stress by even moderate drying. They can maintain efficient photosynthesis under low light conditions, have low chl a/b ratios, and within a limited temperature range their optimum growth is possible. When certain bryophytes' $\mathrm{CO}_{2}$ assimilation is suppressed, photorespiration activity increases and becomes the main electron sink. Bryophytes, as the sensitive components of various vegetation types, are capable of effective light absorption during their desiccation, rehydration, freezing and melting, with the help of coexisting alga and vascular plant energy dissipation mechanisms. They have relatively low optimal temperature for growth (with narrow $\mathrm{T}$ range for net photosynthetic gain), including only minor differences between the optimum temperatures for net photosynthesis in the same species from polar, temperate and tropical populations. Bryophytes have a low acclimatization potential for high temperatures, taking into account that they are generally drought avoiders. Temperature acclimatization potential is of high importance for the physiological basis of altitudinal distribution and the likely responses of bryophytes to climate change. Bryophytes with their small and resistant spores are able to disperse over long distances by wind, which might help their survival in the changing environment. Dominant vascular vegetation might change as temperature will increase; however, suitable microhabitats for bryophytes might still persist. The abundance and species composition of bryophytes in plant communities is predicted to be altered, as well as the function of the whole ecosystem. Based on recent literature and own data, the author makes an attempt to summarize the physiological mechanisms, morphological features and alternative strategies which make bryophytes successful in a constantly changing terrestrial environment. These plants represent a sophisticated solution to the challenges of life at their scale. Further exploration of bryophyte ecophysiology in the changing and stressful environment will provide new information that will assist bryophyte conservation. The research was supported by the grant EFOP-3.6.1-16-201600001 ("Complex improvement of research capacities and services at Eszterhazy Karoly University"). 